\title{
Shading Effects on Leaf Gas Exchange, Leaf Pigments and Secondary Metabolites of Polygonum minus Huds., an Aromatic Medicinal Herb
}

\author{
Fairuz Fatini Mohd Yusof ${ }^{1}$, Jamilah Syafawati Yaacob ${ }^{1} \mathbb{D}$, Normaniza Osman ${ }^{1}$, Mohd Hafiz Ibrahim ${ }^{2}$, \\ Wan Abd Al Qadr Imad Wan-Mohtar ${ }^{3}$, , Zulkarami Berahim ${ }^{4}(\mathbb{D}$ and Nurul Amalina Mohd Zain $1, *(\mathbb{D})$
}

check for updates

Citation: Mohd Yusof, F.F.; Yaacob, J.S.; Osman, N.; Ibrahim, M.H.; Wan-Mohtar, W.A.A.Q.I.; Berahim, Z.; Mohd Zain, N.A. Shading Effects on Leaf Gas Exchange, Leaf Pigments and Secondary Metabolites of Polygonum minus Huds., an Aromatic Medicinal Herb. Plants 2021, 10, 608. https://doi.org/10.3390/

plants10030608

Academic Editor: Ágnes Szepesi

Received: 5 February 2021

Accepted: 10 March 2021

Published: 23 March 2021

Publisher's Note: MDPI stays neutral with regard to jurisdictional claims in published maps and institutional affiliations.

Copyright: (c) 2021 by the authors. Licensee MDPI, Basel, Switzerland. This article is an open access article distributed under the terms and conditions of the Creative Commons Attribution (CC BY) license (https:/ / creativecommons.org/licenses/by/ $4.0 /)$.
1 Faculty of Science, Institute of Biological Sciences, Universiti Malaya, Kuala Lumpur 50603, Malaysia; fatinifairuz@siswa.um.edu.my (F.F.M.Y.); jamilahsyafawati@um.edu.my (J.S.Y.); normaniza@um.edu.my (N.O.)

2 Department of Biology, Faculty of Science, Universiti Putra Malaysia, Serdang 43400, Malaysia; mhafiz_ibrahim@upm.edu.my

3 Functional Omics and Bioprocess Development Laboratory, Faculty of Science, Institute of Biological Sciences, Universiti Malaya, Kuala Lumpur 50603, Malaysia; qadyr@um.edu.my

4 Laboratory of Climate-Smart Food Crop Production, Institute of Tropical Agriculture and Food Security, Universiti Putra Malaysia, Serdang 43400, Malaysia; zulkerami@upm.edu.my

* Correspondence: amalina86@um.edu.my; Tel.: +60-379-674-355

\begin{abstract}
The growing demand for high value aromatic herb Polygonum minus-based products have increased in recent years, for its antioxidant, anticancer, antimicrobial, and anti-inflammatory potentials. Although few reports have indicated the chemical profiles and antioxidative effects of Polygonum minus, no study has been conducted to assess the benefits of micro-environmental manipulation (different shading levels) on the growth, leaf gas exchange and secondary metabolites in Polygonum minus. Therefore, two shading levels (50\%:T2 and 70\%:T3) and one absolute control (0\%:T1) were studied under eight weeks and 16 weeks of exposures on Polygonum minus after two weeks. It was found that $P$. minus under T2 obtained the highest photosynthesis rate $(14.892 \mu \mathrm{mol}$ $\mathrm{CO}_{2} \mathrm{~m}^{-2} \mathrm{~s}^{-1}$ ), followed by $\mathrm{T} 3=\mathrm{T} 1$. The increase in photosynthesis rate was contributed by the enhancement of the leaf pigments content (chlorophyll a and chlorophyll b). This was shown by the positive significant correlations observed between photosynthesis rate with chlorophyll $\mathrm{a}\left(\mathrm{r}^{2}=0.536\right.$; $p \leq 0.05)$ and chlorophyll $\mathrm{b}\left(\mathrm{r}^{2}=0.540 ; p \leq 0.05\right)$. As the shading levels and time interval increased, the production of total anthocyanin content (TAC) and antioxidant properties of Ferric Reducing Antioxidant Power (FRAP) and 2,2-Diphenyl-1-picrylhydrazyl (DPPH) also increased. The total phenolic content (TPC) and total flavonoid content (TFC) were also significantly enhanced under T2 and T3. The current study suggested that P.minus induce the production of more leaf pigments and secondary metabolites as their special adaptation mechanism under low light condition. Although the biomass was affected under low light, the purpose of conducting the study to boost the bioactive properties in Polygonum minus has been fulfilled by $50 \%$ shading under 16 weeks' exposure.
\end{abstract}

Keywords: Polygonum minus; shading levels; growth; leaf gas exchange; leaf pigments; secondary metabolites

\section{Introduction}

Polygonum minus Huds (Family: Polygonaceae), which is commonly known as kesum, is an aromatic herbaceous plant originally located from Southeast Asian countries, such as Malaysia, Thailand, Vietnam, and Indonesia [1]. P. minus is frequently used by the locals in Malaysia as spices and flavouring agents in the delicate local cuisine due to its distinctive and lemony aroma. It has also been traditionally used to treat digestive disorders, dandruff problems and body [2]. Previous research identified that decanal (24.36\%) and dodecanal $(48.18 \%)$ are the two dominant aldehydes that contribute to the flavour of kesum [3]. High 
levels of aliphatic aldehydes (72.54\%) produced in P. minus recognised it as an essential oil-producing crop in the Herbal Product Blueprint by the Malaysian government [4]. It also contains a high level of flavonoid and phenolic compounds, which contributes to its notable bioactive properties, such as antioxidant, antimicrobial, antifungal, antiviral, and antiulcer activities [5]. P. minus has also been reported to exhibit significant reactive oxygen species (ROS) scavenging activities due to its high antioxidant content, and it can be considered to be as one of natural medicinal resources [6]. P. minus was also reported to be able to improve cognitive function and exhibit neuroprotective effect [7]. Currently, few P. minus or kesum-based products have been commercialised, for its antioxidant, anticancer, antimicrobial, and anti-inflammatory potentials [2,5]. The potential of $P$. minus as an anticancer agent was recognised by the display of anti-proliferative activity and apoptosis induction in P. minus on selected cancer and normal cell lines [8]. Another study has succeeded in isolating a new compound from P. minus stems, named Polygonumins A, which was reported to be able to inhibit cancer cells without affecting the normal cells, and have the potential in treating leukaemia [9]. Therefore, the demand of this herb increases due to the high compound of natural antioxidants.

Light intensity is known to regulate not only plant growth and development, but also the biosynthesis of secondary metabolites $[10,11]$. In general, plants living in a full light intensity exhibit different photosynthetic and leaf characteristics than those that are living under the shade. Studies have been carried out to examine environmental stress such as temperature and light on growth and development of several plant species. A study on Orthosiphon stamineus showed that low light helped the plant to produce higher biomass when compared to high light intensity [12]. A similar result was also obtained in Epimedium pseudowushanense exposed to light intensity level of $90.9 \pm 2.5 \mu \mathrm{mol} \mathrm{m}{ }^{-2} \mathrm{~s}^{-1}$ [13]. However, these results were in contrast to that obtained in young tomato plant, which showed that the highest light intensity resulted in the highest accumulation of biomass [14]. It was also reported that low light negatively affects stomatal conductance and it resulted in the enhanced concentration of intercellular $\mathrm{CO}_{2}$ in rice leaves [15]. Meanwhile, another study by Zhu et al., 2017 [16] showed that the chlorophyll b pigments, intracellular $\mathrm{CO}_{2}$ content, and stomatal conductance of the plant Brassica campestris increased under shaded treatments. This indicates that the effects of shadings or light intensity vary with different plant species. Different irradiance levels exposed to plants will also influence and affect the production and accumulation of secondary metabolites. Ghamzadeh et al., 2010 [17] reported that light can stimulate the production of secondary metabolites, such as gingerol and zingiberine in ginger, Zingiber officinale. Meanwhile, another study conducted by Ibrahim et al., 2014 [18] on the plant Labisia pumila showed an increase in the production of secondary metabolites at low light intensity level, along with a high level of $\mathrm{CO}_{2}$.

Currently, the knowledge of different environmental effects on $P$. minus is still limited. Although various reports can be found on the chemical profiles and antioxidative effects of Polygonum minus [3,5], no study was conducted for the effects of shading on the production of secondary metabolites and antioxidant activity in Polygonum minus. A sufficient understanding on the influence of shading towards the growth, leaf gas exchange, and the production of secondary metabolites in $P$. minus are very important for successful cultivation and optimisation in order to utilise this plant's benefit efficiently. This current study was conducted with the objective to examine the effects of different light intensity under different shading levels on the growth, leaf gas exchange, and the accumulation of secondary metabolites of $P$. minus.

\section{Results}

\subsection{Plant Growth}

Plant height $(\mathrm{PH})$ and leaves number $(\mathrm{LN})$ were significantly influenced by the different shading levels. P. minus grown under T2 grew the tallest with $\mathrm{PH}$ of $11.23 \pm 1.197 \mathrm{~cm}$ on the 25th day, followed by T3 $(10.94 \pm 1.234 \mathrm{~cm})$ and T1 $(9.54 \pm 0.895 \mathrm{~cm})$ (Figure 1). Data analysis shows that T3 resulted in the increment of plant height, but the results 
dropped after the 17th day and they showed the lowest drop on the 21st day, due to wilting symptoms that were exhibited by a few plants. This sudden drop trend on the 21st day can also be seen in LN (Figure 2).

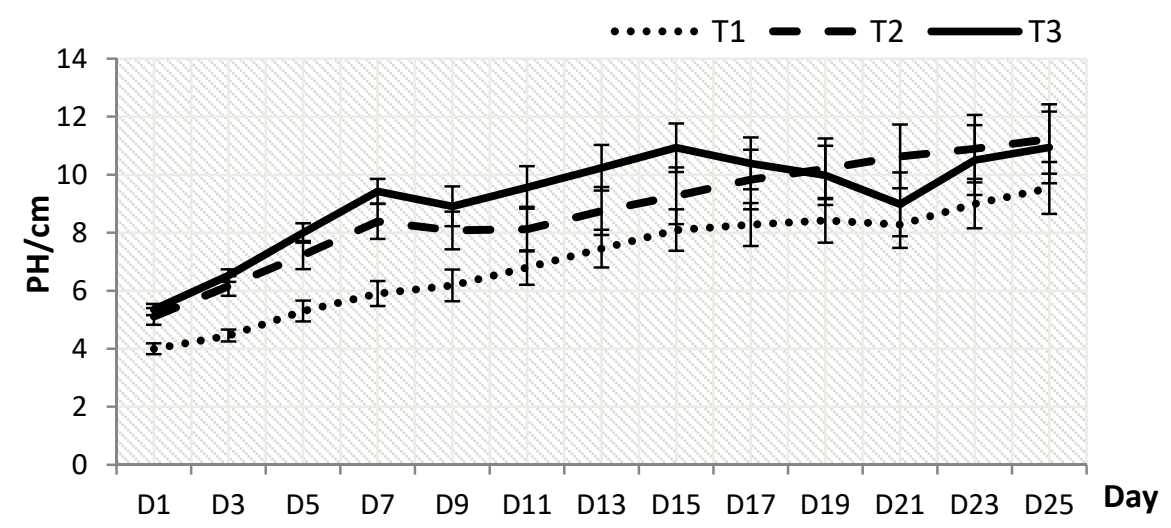

Figure 1. Effect of shading levels on plant height, $\mathrm{PH}$ (Data are means of treatments, $N=96$; Rep $=4$; Control, T1 = 0\% Shaded; T2 = 50\% Shading and T3 = 70\% Shading; Small bars represent standard error).

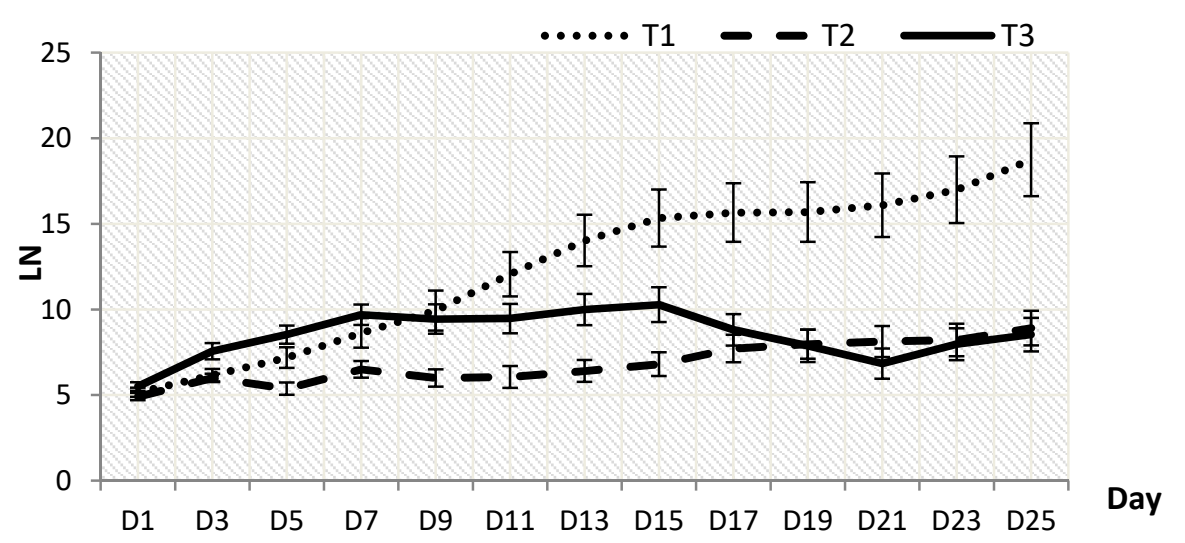

Figure 2. Effect of shading levels on leaves number, LN (Data are means of treatments, $N=96$; Rep $=4 ;$ Control, $\mathrm{T} 1=0 \%$ Shading; $\mathrm{T} 2=50 \%$ Shading and T3 $=70 \%$ Shading; Small bars represent standard error).

T1 resulted in the highest $\mathrm{LN}(18.75 \pm 2.133)$, which was $52.5 \%$ higher when compared to T2 $(8.91 \pm 1.011)$ and $54.5 \%$ more as compared to T3 $(8.53 \pm 0.979)$ recorded on the 25 th day (Figure 2). The decreasing trend under T3 was observed to occur from the 17th day until the 21st day before re-increasing in number on the 23rd day, possibly due to the low light penetration that caused LN reduction in P. minus. Meanwhile, a constant increasing trend was observed under $\mathrm{T} 2$ starting on the 9 th day. $\mathrm{PH}$ had positively correlated with $\mathrm{LN}\left(\mathrm{r}^{2}=0.692, p \leq 0.01\right)$.

\subsection{Biomass Dry Weight and Root-Shoot Ratio(RSR)}

Leaf dry weight (LDW), shoot dry weight (SDW), and root dry weight (RDW) that were harvested under time interval of 16 weeks were significantly influenced by different shading levels $(p \leq 0.05)$, while there are no significant differences among SDW and RDW under time interval of eight weeks excluding LDW. Under eight weeks, the lowest LDW found on T3 and T2. Figure 3a,b show control, T1 achieved the highest LDW and SDW in eight weeks and 16 weeks. On 16 weeks, the RDW obtained by T1 showed distinct root dry weight compared to T2 and T3. For RSR, there is no significant difference found on both time intervals. Pearson's correlation shows that LDW has a strong correlation with SDW $\left(\mathrm{r}^{2}=0.988, p \leq 0.01\right)$ and RDW $\left(\mathrm{r}^{2}=0.985, p \leq 0.01\right)$. 


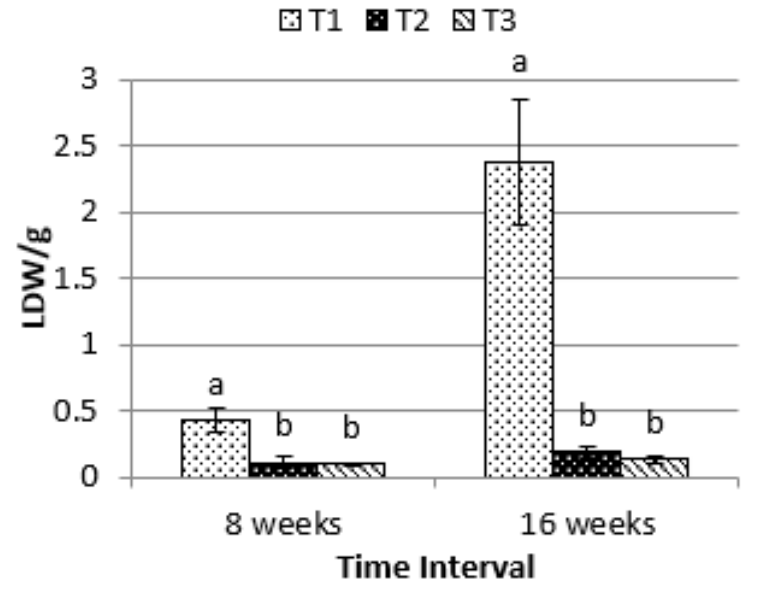

(a)

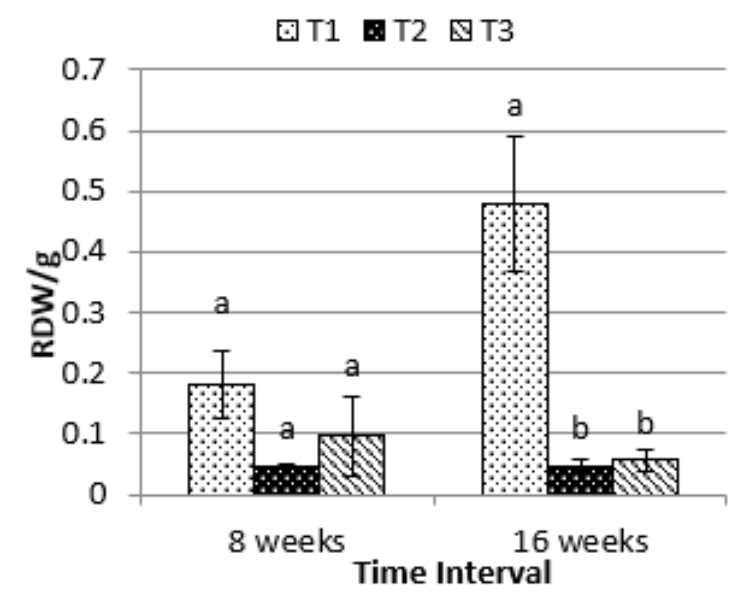

(c)

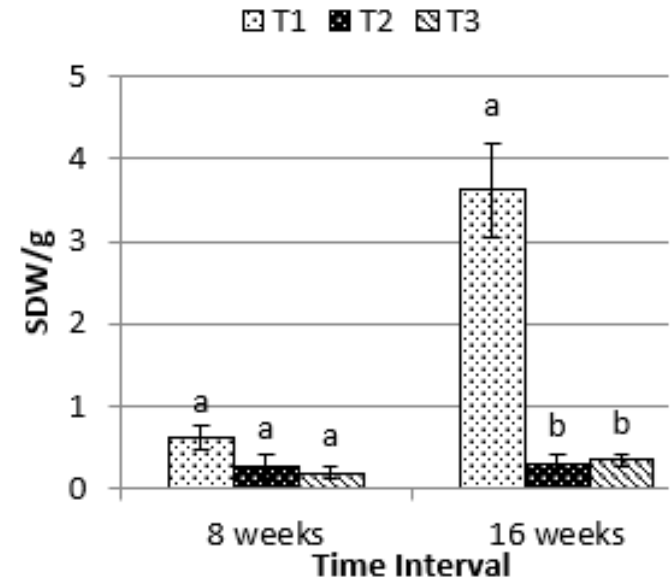

(b)

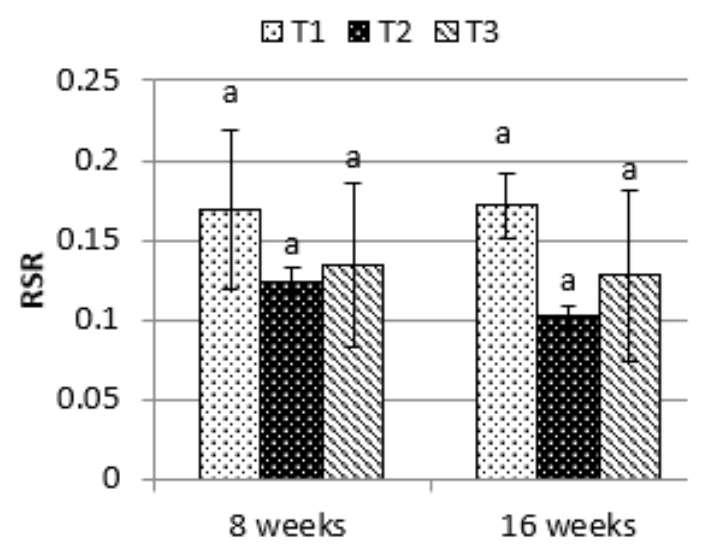

Time Interval

(d)

Figure 3. Effects of different shading levels (T1 = $0 \%$; T2 $=50 \%$ and T3 $=70 \%$ ) on (a) LDW, leaf dry weight; (b) SDW, shoot dry weight; (c) RDW, root dry weight; and, (d) RSR, root-shoot ratio under time interval of eight weeks and 16 weeks) (data are means of treatments, $N=48$; Rep $=4$; Control, T1 = $\%$ Shading; T2 = 50\% Shading and T3 = 70\% Shading; Small bars represent standard error). Means with different letters on top of each bar are significantly different at $p \leq 0.05$.

\subsection{Leaf Gas Exchange, Leaf Pigments and In-Situ Chlorophyll}

The highest photosynthesis rate (A) was observed under T2 $(14.89 \pm 3.65 \mu \mathrm{mol}$ $\mathrm{CO}_{2} \mathrm{~m}^{-2} \mathrm{~s}^{-1}$ ), followed by T3 $=\mathrm{T} 1$. The same trend was observed for leaf temperature (Tleaves) with the highest value being recorded in plants under T2 $\left(36.10 \pm 1.061{ }^{\circ} \mathrm{C}\right)$ and the lowest temperature under $\mathrm{T} 1\left(33.81 \pm 0.115^{\circ} \mathrm{C}\right)$, as in Table 1. Other leaf gas exchange properties, such as the transpiration rate (E) and stomatal conductance (Gs), were also found to be significantly influenced by different shade levels $(p \leq 0.01)$. The highest E $\left(0.3399 \pm 0.0008 \mathrm{mmol} \mathrm{H}_{2} \mathrm{O} \mathrm{m}^{-2} \mathrm{~s}^{-1}\right)$ and $\mathrm{Gs}\left(0.007 \pm 0.034 \mathrm{~mol} \mathrm{H}_{2} \mathrm{O} \mathrm{m}^{-2} \mathrm{~s}^{-1}\right)$ were recorded under T2 $>$ T1 $=$ T3. Significant positive correlations (Table 2) were observed between A and leaf pigments, such as Chl a $\left(\mathrm{r}^{2}=0.536, p \leq 0.05\right)$, with Chl b $\left(\mathrm{r}^{2}=0.540\right.$, $p \leq 0.05)$ and with Chl a $+\mathrm{b}\left(\mathrm{r}^{2}=0.546, p \leq 0.05\right)$, which indicates that the increase in leaf pigments would increase the photosynthesis rate. There is also high positive correlation between $\mathrm{E}$ and $\mathrm{Chl} \mathrm{a}\left(\mathrm{r}^{2}=0.652, p \leq 0.05\right)$, and $\mathrm{Chl} \mathrm{b}\left(\mathrm{r}^{2}=0.553, p \leq 0.05\right)$. Additionally, Gs were also shown to be positively correlated with $\mathrm{Chl} \mathrm{a}\left(\mathrm{r}^{2}=0.62, p \leq 0.05\right)$. These show that leaf gas exchange properties increase with the increase of leaves pigment content. 
Table 1. The effects of the different shading levels on the leaf gas exchange and leave pigments of $P$. minus (data are means of treatments, $N=48$; Rep $=4$; Control, $\mathrm{T} 1=0 \%$ Shading; $\mathrm{T} 2=50 \%$ Shading and T3 = 70\% Shading; FW $=$ Fresh Weight; Means with different letters on top of each standard error of means are significantly different at $p \leq 0.05$ between shading treatments).

\begin{tabular}{|c|c|c|c|c|}
\hline Treatments & & T1 & T2 & T3 \\
\hline \multirow{4}{*}{ Leaf gas exchange } & $\mathrm{A}\left(\mu \mathrm{mol} \mathrm{CO} \mathrm{m}^{-2} \mathrm{~s}^{-1}\right)$ & $6.845 \pm 1.68 \mathrm{~b}$ & $14.892 \pm 3.65 \mathrm{a}$ & $6.860 \pm 2.36 b$ \\
\hline & Tleaves $\left({ }^{\circ} \mathrm{C}\right)$ & $33.81 \pm 0.381 \mathrm{~b}$ & $36.10 \pm 1.061 \mathrm{a}$ & $35.69 \pm 0.432 \mathrm{a}$ \\
\hline & $\mathrm{E}\left(\mathrm{mmol} \mathrm{H} \mathrm{O} \mathrm{m}^{-2} \mathrm{~s}^{-1}\right)$ & $0.259 \pm 0.0008 \mathrm{~b}$ & $0.3399 \pm 0.0008 \mathrm{a}$ & $0.282 \pm 0.0008 b$ \\
\hline & $\mathrm{Gs}\left(\mathrm{mol} \mathrm{H} \mathrm{O}_{2} \mathrm{~m}^{-2} \mathrm{~s}^{-1}\right)$ & $0.006 \pm 0.00078 \mathrm{~b}$ & $0.007 \pm 0.00083 \mathrm{a}$ & $0.0058 \pm 0.000818 \mathrm{~b}$ \\
\hline \multirow{6}{*}{ Pigments } & Chl a $\left(\mathrm{mg} \mathrm{g}^{-1} \mathrm{FW}\right)$ & $2.843 \pm 0.128 \mathrm{c}$ & $5.251 \pm 0.539 a$ & $3.9 \pm 0.161 b$ \\
\hline & Chl b (mg g $\left.{ }^{-1} \mathrm{FW}\right)$ & $3.308 \pm 0.031 \mathrm{bc}$ & $5.317 \pm 0.785 \mathrm{a}$ & $3.848 \pm 0.338 \mathrm{ab}$ \\
\hline & Car $\left(\mathrm{mg} \mathrm{g}^{-1} \mathrm{FW}\right)$ & $1.474 \pm 0.052 \mathrm{bc}$ & $2.771 \pm 0.369 \mathrm{a}$ & $2.244 \pm 0.195 \mathrm{ab}$ \\
\hline & $\left.\mathrm{Chl} \mathrm{a} \mathrm{+} \mathrm{b} \mathrm{(mg} \mathrm{g}{ }^{-1} \mathrm{FW}\right)$ & $6.151 \pm 0.144 \mathrm{bc}$ & $10.568 \pm 1.324 \mathrm{a}$ & $7.748 \pm 0.497 \mathrm{ab}$ \\
\hline & $\mathrm{a} / \mathrm{b}$ ratio & $0.859 \pm 0.036 \mathrm{a}$ & $1.013 \pm 0.058 \mathrm{a}$ & $1.029 \pm 0.046 \mathrm{a}$ \\
\hline & SPAD & $26.258 \pm 0.822 c$ & $33.716 \pm 1.198 \mathrm{a}$ & $30.305 \pm 0.916 b$ \\
\hline
\end{tabular}

Note: A: Photosynthesis rate, Tleaves: Leaf temperature, E: Transpiration rate, Gs: Stomatal conductance, Chl a: Chlorophyll a, Chl b: Chorophyll b, Chl a + b: Total chlorophyll content, Car: Carotenoid, a/b ratio: Chlorophyll a and b ratio, SPAD: In-situ chlorophyll.

Leaf pigment contents were expressed as $\mathrm{mg} \mathrm{g}^{-1}$ fresh weight (FW) were significantly influenced by different shading levels. The highest $\mathrm{Chl} \mathrm{a}\left(5.251 \pm 0.539 \mathrm{mg} \mathrm{g}^{-1} \mathrm{FW}\right), \mathrm{Chl}$ $\mathrm{b}\left(5.317 \pm 0.785 \mathrm{mg} \mathrm{g}^{-1} \mathrm{FW}\right), \mathrm{Chl} \mathrm{a}+\mathrm{b}\left(10.568 \pm 1.324 \mathrm{mg} \mathrm{g}^{-1} \mathrm{FW}\right)$, and Car content $\left(2.771 \pm 0.369 \mathrm{mg} \mathrm{g}^{-1} \mathrm{FW}\right)$ were obtained under T2, followed by T3 and the lowest under T1. However, there was non-significant difference between the treatments $(p>0.05)$ for chlorophyll $\mathrm{a} / \mathrm{b}$ ratio. The highest in-situ chlorophyll content (SPAD) value was obtained under T2 (33.716 \pm 1.198$)$, followed by T3 (30.305 \pm 0.916$)$ and the lowest was under $\mathrm{T} 1$ (26.258 \pm 0.822$)$, where the values were significantly influenced by different shading levels. Table 1 shows all data. The rranspiration rate was positively correlated with Chl a $\left(\mathrm{r}^{2}=0.652 ; p \leq 0.05\right), \mathrm{Chl} \mathrm{b}\left(\mathrm{r}^{2}=0.553 ; p \leq 0.05\right)$, and Chl a $+\mathrm{b}\left(\mathrm{r}^{2}=0.61 ; p \leq 0.05\right)$ (Table 2).

\subsection{Total Anthocyanin, Phenolic, and Flavonoid Content}

The TAC, TPC, and TFC of P. minus leaves were significantly influenced by different shading levels. Under time interval of eight weeks, T3 recorded the highest TAC $\left(88.597 \pm 19.368 \mu \mathrm{g} \mathrm{g}^{-1}\right.$ dry weight $\left.(\mathrm{DW})\right)$, followed by T2 $\left(57.055 \pm 13.18 \mu \mathrm{g} \mathrm{g}^{-1} \mathrm{DW}\right)$, and the lowest was obtained by T1 $\left(29.90 \pm 3.831 \mu^{g_{g} g^{-1}}\right.$ DW) (Figure 4). However, when the plants were exposed with longer treatment duration of 16 weeks, T2 was observed to yield the highest TAC $\left(65.961 \pm 5.205 \mu \mathrm{g} \mathrm{g}^{-1} \mathrm{DW}\right)$, followed by T3 $>$ T1 (Figure 4). Table 2 shows that there was a strong correlation observed between TAC with Car $\left(\mathrm{r}^{2}=0.549\right.$, $p \leq 0.05)$.

Conversely, the highest TPC under eight weeks $\left(198.286 \pm 7.193 \mathrm{mg} \mathrm{g}^{-1} \mathrm{DW}\right)$ was obtained under T2. Meanwhile, after 16 weeks of treatment exposure, the highest TPC was recorded under T3, with values of $362.323 \pm 65.990 \mathrm{mg} \mathrm{g}^{-1} \mathrm{DW}$ (Figure 5). The same trend was observed for TFC, where the highest flavonoid content was recorded under T3 (180.651 $\left.\pm 4.219 \mathrm{mg} \mathrm{g}^{-1} \mathrm{DW}\right)$ after 16 weeks of exposure (Figure 6). 


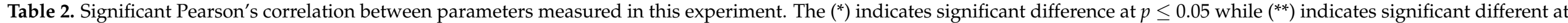
$p \leq 0.01$.

\begin{tabular}{|c|c|c|c|c|c|c|c|c|c|c|c|c|c|c|c|c|c|c|c|c|}
\hline & & 1 & 2 & 3 & 4 & 5 & 6 & 7 & 8 & 9 & 10 & 11 & 12 & 13 & 14 & 15 & 16 & 17 & 18 & 19 \\
\hline 1 & $\mathrm{PH}$ & 1 & 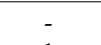 & - & & & & & & & & & & & & & & & & \\
\hline 2 & LN & $0.692 * *$ & 1 & - & & & & & & & & & & & & & & & & \\
\hline 3 & LDW & -0.276 & 0.212 & 1 & & & & & & & & & & & & & & & & \\
\hline 4 & SDW & -0.185 & 0.266 & $0.988^{* *}$ & 1 & & & & & & & & & & & & & & & \\
\hline 5 & RDW & -0.184 & 0.264 & 0.985 ** & $0.998^{* *}$ & 1 & & & & & & & & & & & & & & \\
\hline 6 & RSR & -0.500 & 0.008 & 0.793 ** & $0.746^{* *}$ & $0.764^{* *}$ & 1 & & & & & & & & & & & & & \\
\hline 7 & A & -0.088 & -0.210 & -0.040 & 0.044 & 0.045 & -0.162 & 1 & & & & & & & & & & & & \\
\hline 8 & $\mathrm{E}$ & 0.075 & -0.495 & -0.326 & -0.300 & -0.323 & -0.441 & 0.242 & 1 & & & & & & & & & & & \\
\hline 9 & Gs & 0 & -0.530 & -0.335 & -0.304 & -0.326 & -0.434 & 0.313 & $0.972 * *$ & 1 & & & & & & & & & & \\
\hline 10 & Tleaves & 0.484 & 0.026 & -0.209 & -0.189 & -0.199 & -0.344 & -0.104 & 0.501 & & 1 & & & & & & & & & \\
\hline 11 & Chl a & 0.342 & -0.277 & -0.398 & -0.314 & -0.316 & $-0.557^{*}$ & $0.536^{*}$ & 0.652 * & 0.620 * & $\begin{array}{c}1 \\
0.468\end{array}$ & 1 & & & & & & & & \\
\hline 12 & Chl b & 0.145 & -0.367 & -0.304 & -0.254 & -0.255 & -0.394 & 0.540 * & 0.553 * & 0.508 & 0.416 & $0.939 * *$ & 1 & & & & & & & \\
\hline 13 & Car & 0.311 & -0.254 & -0.397 & -0.329 & -0.333 & -0.595 * & 0.482 & 0.513 & 0.477 & 0.42 & 0.963 ** & $0.946^{* *}$ & 1 & & & & & & \\
\hline 14 & $\mathrm{Chl} a+b$ & 0.244 & -0.329 & -0.355 & -0.287 & -0.289 & -0.480 & $0.546^{*}$ & $0.610^{*}$ & 0.570 * & 0.448 & 0.984 ** & $0.986^{* *}$ & $0.969^{* *}$ & 1 & & & & & \\
\hline 15 & $\mathrm{a} / \mathrm{b}$ ratio & 0.524 & 0.262 & -0.263 & -0.164 & -0.168 & -0.475 & 0.033 & 0.239 & 0.282 & 0.105 & 0.149 & -0.196 & 0.038 & -0.030 & 1 & & & & \\
\hline 16 & SPAD & 0.586 * & 0.089 & -0.330 & -0.321 & -0.321 & -0.448 & -0.195 & 0.388 & 0.213 & $0.850 * *$ & 0.463 & 0.43 & 0.456 & 0.453 & 0.027 & 1 & & & \\
\hline 17 & TAC & -0.094 & -0.410 & -0.382 & -0.330 & -0.331 & -0.552 & 0.483 & 0.309 & 0.434 & -0.255 & 0.522 & 0.413 & $0.549^{*}$ & 0.473 & 0.351 & -0.103 & 1 & & \\
\hline 18 & TPC & $0.805^{* *}$ & 0.361 & -0.281 & -0.204 & -0.212 & -0.553 * & $\begin{array}{l}.403 \\
0.072\end{array}$ & 0.357 & $\begin{array}{l}0.454 \\
0.212\end{array}$ & $0.798^{* *}$ & 0.529 & $\begin{array}{l}.410 \\
0.39\end{array}$ & 0.498 & 0.464 & 0.36 & $0.744^{* *}$ & -0.119 & 1 & \\
\hline 19 & TFC & 0.845 ** & 0.498 & -0.428 & -0.365 & -0.378 & $-0.680 *$ & -0.162 & 0.154 & 0.029 & $0.663 *$ & 0.353 & 0.192 & 0.387 & 0.274 & 0.445 & 0.644 * & -0.085 & $0.889 * *$ & 1 \\
\hline
\end{tabular}

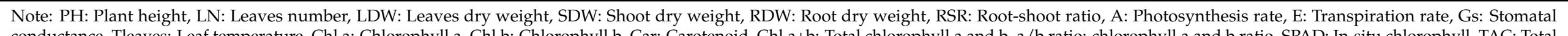
anthocyanin content, TPC: Total phenolic cotent, TFC: Total flavonoid Chlorophy 


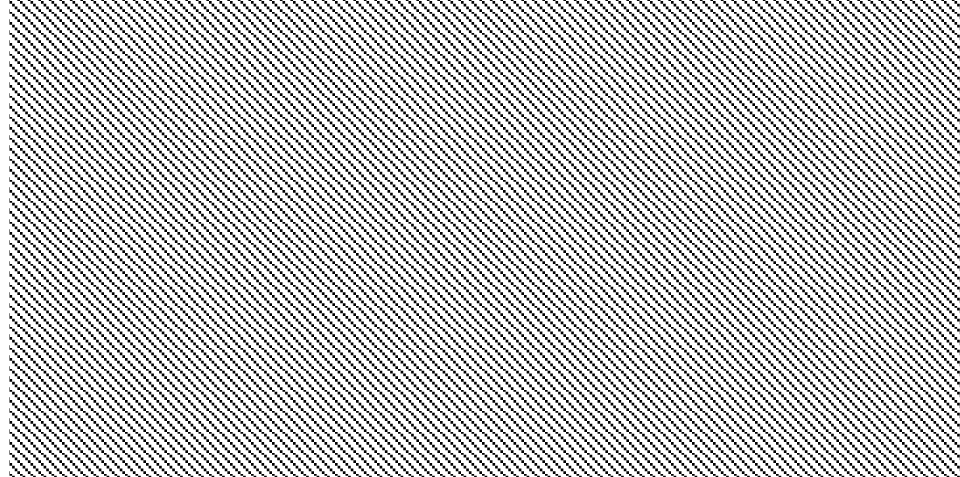

Figure 4. Effects of different shading levels on the total anthocyanin content of P. minus (data are means of treatments; $N=36$; Rep = 3; Control, T1 = 0\% Shading; T2 = 50\% Shading; and, T3 = 70\% Shading; DW = Dry Weight). Means with different letters on top of each bar are significantly different at $p \leq 0.05$.

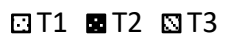

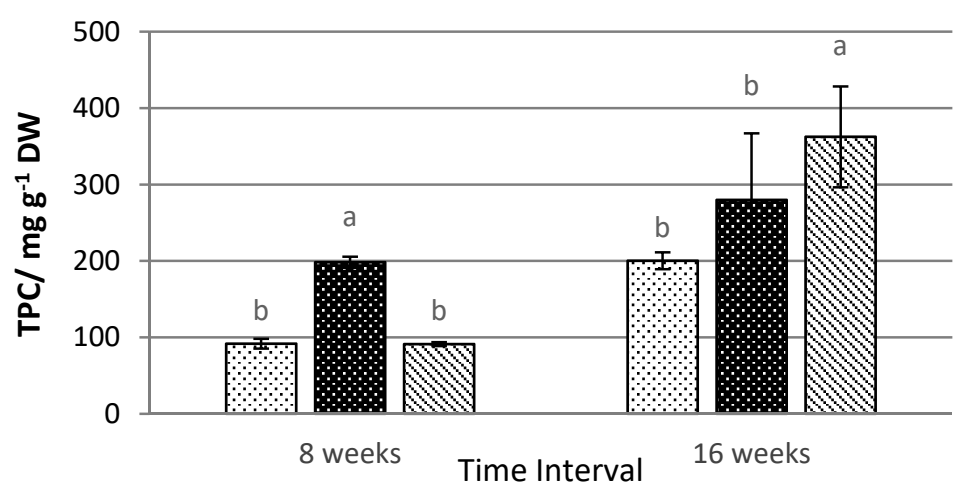

Figure 5. The effects of different shading levels on the total phenolic content of $P$. minus (data are means of treatments, $N=36$; Rep $=3$; Control, $\mathrm{T} 1=0 \%$ Shading; $2=50 \%$ Shading and T3 $=70 \%$ Shading; DW = Dry Weight). Means with different letters on top of each bar are significantly different at $p \leq 0.05$.

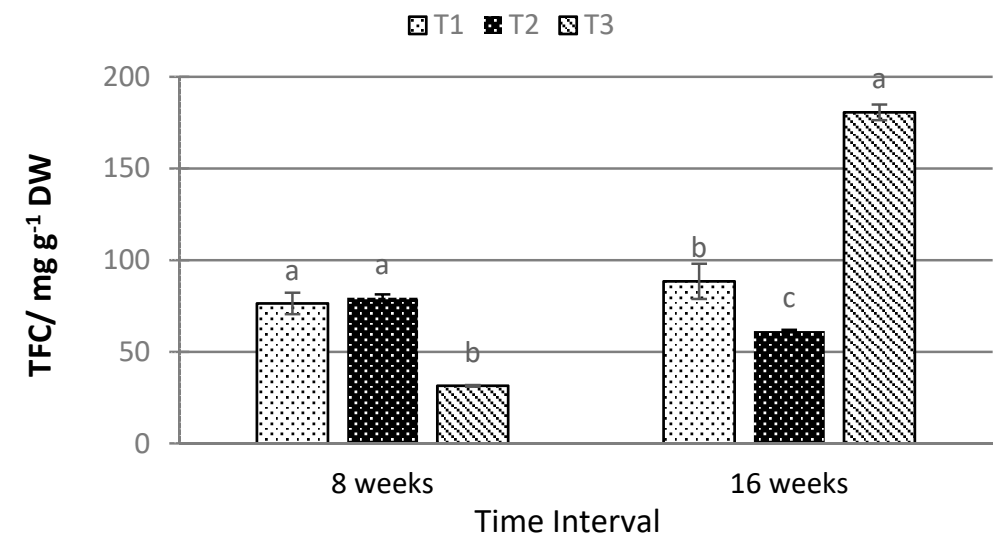

Figure 6. Effects of different shade levels on the total flavonoid content of $P$. minus (data are means of treatments, $\mathrm{N}=36$; Rep = 3; Control, $\mathrm{T} 1=0 \%$ Shading; $\mathrm{T} 2=50 \%$ Shading and $\mathrm{T} 3=70 \%$ Shading; $\mathrm{DW}=$ Dry Weight). Means with different letters on top of each bar are significantly different at $p \leq 0.05$.

Significant positive correlations can be seen between TPC and TFC with in-situ chlorophyll, SPAD $\left(\mathrm{r}^{2}=0.744, p \leq 0.01\right.$ and $\mathrm{r}^{2}=0.644 ; p<0.05$ (Table 2$)$, respectively. High 
significant correlations are also observed between TPC and TFC with Tleaves. with $\mathrm{r}^{2}$ values of $0.798, p \leq 0.01$ and $0.693, p \leq 0.05$.

\subsection{Radical Scavenging Assays}

The dry extract (DE) of the leaves from P. minus was also examined for its antioxidant capabilities. FRAP and DPPH radical scavenging assays were used to measure its antioxidant capacity. Table 3 presents the FRAP and the $\mathrm{IC}_{50}$ values. The interaction effect between shading treatments and time interval were both significantly different for the measurement of FRAP reducing power and $\mathrm{IC}_{50}$ values of DPPH. The highest FRAP reducing power was recorded under T2 of 16 weeks $\left(2.616 \pm 0.071 \mathrm{mg} \mathrm{g}^{-1} \mathrm{DE}\right)$, followed by T1 eight week time interval $\left(2.041 \pm 0.004 \mathrm{mg} \mathrm{g}^{-1} \mathrm{DE}\right)$ and the leaves extract under T3 have the lowest FRAP reducing power $\left(1.457 \pm 0.036 \mathrm{mg} \mathrm{g}^{-1} \mathrm{DE}\right)$. The measurement for the highest FRAP reducing power was also parallel to the lowest concentration that is needed in order to inhibit $50 \%$ of the non-radical 1,1- diphenyl-2-picryl hydrazine. Leaves extract under T2 time interval of 16 weeks needed only $0.657 \mathrm{mg} \mathrm{mL}^{-1}$ of the extract to exhibit $50 \%$ inhibition, followed by $\mathrm{T} 3$ under time interval of 16 weeks. The highest $\mathrm{IC}_{50}$ were obtained under T1 time interval of 16 weeks, but the value was not significantly different when compared to the value of $\mathrm{IC}_{50}$ obtained under $\mathrm{T} 1$ time interval of eight weeks. Overall, the antioxidant capacities of P. minus were the highest under a T2 time interval of 16 weeks.

Table 3. The effects of the different shade levels on antioxidant activities of P. minus extract. (Data are means of treatments, $N=36$; Rep = 3; Control, T1 = 0\% Shading; T2 = 50\% Shading; and, T3=70\% Shading; DE: Dry Extract; means with different letters on top of each standard error of means are significantly different at $p \leq 0.05$ between shade levels).

\begin{tabular}{|c|c|c|c|c|}
\hline \multirow{2}{*}{ Treatments } & \multicolumn{2}{|c|}{ FRAP (mg g ${ }^{-1}$ DE) } & \multicolumn{2}{|c|}{ DPPH IC $50\left(\mathrm{mg} \mathrm{mL}^{-1}\right)$} \\
\hline & 8 Weeks & 16 Weeks & 8 Weeks & 16 Weeks \\
\hline $\mathrm{T} 1$ & $2.041 \pm 0.004 \mathrm{ab}$ & $1.930 \pm 0.404 \mathrm{ab}$ & $3.338 \pm 0.001 \mathrm{a}$ & $4.202 \pm 0.423 \mathrm{a}$ \\
\hline $\mathrm{T} 2$ & $1.933 \pm 0.016 \mathrm{ab}$ & $2.616 \pm 0.071 \mathrm{a}$ & $2.543 \pm 0.001 \mathrm{ab}$ & $0.657 \pm 0.007 \mathrm{~b}$ \\
\hline T3 & $1.641 \pm 0.019 \mathrm{~b}$ & $1.457 \pm 0.036 \mathrm{bc}$ & $2.168 \pm 0.340 \mathrm{ab}$ & $1.949 \pm 0.571 \mathrm{ab}$ \\
\hline
\end{tabular}

High positive significant correlation can be seen between FRAP with Chl a $\left(\mathrm{r}^{2}=0.734\right.$; $p<0.01)$, Chl b ( $\left.\mathrm{r}^{2}=0.598 ; p<0.05\right)$, Car $\left(\mathrm{r}^{2}=0.707 ; p<0.01\right)$, and TAC $\left(\mathrm{r}^{2}=0.859\right.$; $p<0.01$ ). This means that, as the respective values increase, the FRAP reducing power will also increase. Meanwhile, DPPH was only negatively correlated with TAC $\left(\mathrm{r}^{2}=-0.666\right.$; $p<0.05)$. A significant negative relationship can also be seen between DPPH and FRAP $\left(\mathrm{r}^{2}=-0.59 ; p<0.05\right)$. No significant correlation can be seen between both antioxidant assays with TPC and TFC. Table 4 records these correlation data.

Table 4. Significant Pearson's correlation between secondary metabolites and antioxidant activities. The $\left(^{*}\right)$ indicates significant difference at $p \leq 0.05$, while $\left.{ }^{* *}\right)$ indicates significant different at $p \leq 0.01$.

\begin{tabular}{ccccccccc}
\hline & & $\mathbf{1}$ & $\mathbf{2}$ & $\mathbf{3}$ & $\mathbf{4}$ & $\mathbf{5}$ & $\mathbf{6}$ & $\mathbf{7}$ \\
\hline 1 & Chl a & 1 & & & & & & \\
2 & Chl b & $0.939 * *$ & 1 & & & & & \\
3 & Car & $0.963^{* *}$ & $0.946^{* *}$ & 1 & & & & \\
4 & TAC & 0.522 & 0.413 & $0.549^{*}$ & 1 & & & \\
5 & TPC & 0.529 & 0.390 & 0.498 & -0.119 & 1 & & \\
6 & TFC & 0.353 & 0.192 & 0.387 & -0.085 & $0.889 * *$ & 1 & 1 \\
7 & FRAP & $0.734^{* *}$ & $0.598^{*}$ & $0.707^{* *}$ & $0.859^{* *}$ & 0.246 & 0.185 & 1 \\
8 & DPPH & -0.209 & -0.110 & -0.330 & $-0.666^{*}$ & -0.034 & -0.202 & $-0.590^{*}$ \\
\hline
\end{tabular}

Chl a: Chlorophyll a, Chl b: Chlorophyll b, Car: Carotenoid, TAC: Total anthocyanin content, TPC: Total phenolic content, TFC: Total flavonoid content, FRAP: Ferric Reducing Antioxidant Power, DPPH: 2,2-diphenyl-1-picryl-hydrazyl-hydrate. 


\section{Discussion}

Based on overall data analysed, the different shading levels highly influenced the P. minus growth, leaf gas exchange properties, leaf pigments, and secondary metabolites. Referring to the growth data, $\mathrm{PH}$ and $\mathrm{LN}$ were significantly influenced by the difference shading levels, where the highest $\mathrm{PH}$ was obtained under $\mathrm{T} 2$ with $50 \%$ shading or $50 \%$ light penetration to the plant on 25th day (Figure 1). It was reported that the responses of plants towards high shading level (low light intensity) are many and varied between plant species, but rapid and higher growth, or growth towards light (phototropism), are common changes that could be observed [19-21]. Henceforth, the investment of plant in height will indirectly improve the access of plants towards light for better light absorbance and photosynthesis process [22], especially under shading condition. These findings are in agreement with the results that were reported by other studies on Baccharis trimera and Aloe vera, which showed that the plants grow taller in shading environment $[23,24]$. The increase in $\mathrm{PH}$ under lower light intensity could also be attributed to the production of auxin that is triggered by the stress and, thus, helps to accelerate shoot elongation [25]. Another study on tobacco seedlings [26] also showed the production of taller plants under low irradiance.

However, LN was observed to increase under control, zero shading, which showed the highest LDW under T1 on the 25th day (Figure 2). The results suggested that the increase in shading levels would decrease the number of leaves that were produced in plants, as plants may be focusing more on enlarging the size of the leaves by cell multiplication, instead of producing more leaves in order to be able to absorb sunlight more efficiently $[27,28]$. A high LN under T1 indicates that zero shading may improve the leaves biomass of P. minus, and these results are aligned with the findings that were recorded in common sage (Salvia officinalis L.), which showed that sage plants produced a greater number of leaves and exhibited higher productivity under high light intensity [29].

Besides different shading levels that were subjected onto the plants, the duration of exposure also showed significant results on the biomass of $P$. minus. An increasing trend could be observed between dry weights of plants from time interval of eight weeks and 16 weeks, even under low light intensity. This suggests the adaptability of $P$. minus towards low light intensity, as the plants managed to strive in terms of growth. Nevertheless, low LDW can be observed under shaded conditions T2 and T3, which suggests that low light intensities limit the leaves growth of P. minus. The highest SDW obtained under T1 and lower RDW that were obtained under T2 and T3 were parallel to the results obtained in a study on Aloe vera, which obtained twice higher dry mass of shoot under full sunlight and concluded that the reduced dry mass of root was caused by a restriction of carbon allocations to roots under low irradiance [23]. In addition, low light intensity will also cause a limitation in the supply of carbohydrates from the photosynthesis process, which will affect the roots more when compared to the shoots, as roots depend on the shoots for carbohydrate [30]. RSR was not significantly influenced by the different shading levels, which aligned with the study that was reported by Jose et al., 2002 [31] where light exerted no significant influence on the root:shoot ratio, highlighting that root:shoot ratio changes were commonly found under nutrient stress. Nevertheless, favourable condition for plants in many aspects, such as the soil water content, surrounding temperature, good irrigation, fertilization practices, and the light intensity level around the plants, may result in a reduced root-shoot ratio [32]. The allocation of plant parts biomass between leaves, shoots, and roots depends on species, ontogeny, and on the environment around the plants [33]. There was no fixed pattern observed for this allocation in P. minus under light stress from this study. Strong positive correlation can be seen between SDW and RDW $\left(\mathrm{r}^{2}=0.998 ; p \leq 0.01\right)$ (Table 2). High interaction between LDW and SDW $\left(\mathrm{r}^{2}=0.988\right.$; $p \leq 0.01)$ and between LDW and RDW $\left(\mathrm{r}^{2}=0.985 ; p \leq 0.01\right)$ can also be observed from Table 2. These correlations suggest that, as LDW increase, the SDW and RDW will also increase. Changes in the allocation of dry mass between roots and shoots may enable plants under stress conditions to be able to obtain enough absorption of water and nutrient [34]. 
A balanced growth of plants hypothesis suggests that the plants favour more in allocating biomass to the organ that is harvesting the resources, such as leaves and roots, to increase resource capture following the imbalance of carbon fixation and soil nutrient gain, as the environment condition and resources availability will often fluctuate in nature [35].

The significant influence of the different shade levels on $P$. minus exhibit the highest photosynthetic rate under intermediate light intensity T2 (Table 1). Plants under high irradiance would commonly have higher photosynthesis rate when compared to plants under the shade [33]. However, a previous study on Salvia officinalis reported that long exposure of plants under high light intensity might damage the photosynthesis apparatus, which leads to its partial loss of the photosynthetic function [29]. A study on Eugenia uniflora L. also reported that plant leaves showed lower photosynthetic pigment contents under high light intensity as compared to low light intensity, although the chlorophyll pigment will usually be synthesised and photo-oxidised under the presence of light, but excessive light may cause great degradation in the green pigmentation [36]. Plants that are grown under low light intensity are known to optimise the photosynthesis process efficiently by increasing the pigment density per unit leaf area [37]. The present study showed that the highest photosynthesis rate of $P$. minus was under $\mathrm{T} 2$, being directly proportional to the leaf pigment contents, which were also found to be the highest under T2 (Table 1). A study on safflower [38] also found that a higher photosynthesis rate in the subject was accompanied by a higher content in chlorophyll. A strong positive correlation can be observed between the photosynthesis rate and leaf pigment, $\mathrm{Chl} \mathrm{a}\left(\mathrm{r}^{2}=0.536, p \leq 0.01\right)$, $\mathrm{Chl} \mathrm{b}\left(\mathrm{r}^{2}=0.540, p \leq 0.01\right)$ and $\mathrm{Chl} \mathrm{a}+\mathrm{b}\left(\mathrm{r}^{2}=0.546, p \leq 0.01\right)$ (Table 2). It is also more useful to express photosynthesis relative to leaf chlorophyll, as it could reflect the balance in the investment between the capture and utilisation of light [39]. In-situ chlorophyll was the highest under T2 (Table 2), being parallel to the results that were obtained for chlorophyll a and chlorophyll b contents, which were also the highest under T2.

Carotenoids are one of plant synthesised secondary metabolites that act as important radical scavengers [40]. This study showed that $50 \%$ shading level under T2 significantly enhanced the production of carotenoid in the leaves of P. minus along with the enhancement of chlorophyll content (Table 1), and this observation was supported by strong correlation found between the Car with Chl a $\left(\mathrm{r}^{2}=0.963 ; p \leq 0.01\right)$ and Chl b $\left(\mathrm{r}^{2}=0.946 ; p \leq 0.01\right)$ (Table 2). Similar findings were observed in a study conducted by Bohne and Linden 2002 [41], which showed the highest chlorophyll and carotenoid content were produced when Chlamydomonas reinhardtii was grown under low light conditions. The previous study emphasized that the increase in carotenoid may not only depend on the expression of phytoene synthase, but also on the biosynthesis of chlorophyll. The chlorophyll $\mathrm{a} / \mathrm{b}$ ratio of $P$. minus was not significantly influenced by different shading levels. A decrease in chlorophyll $\mathrm{a} / \mathrm{b}$ ratio indicates an increase in the amount of chlorophyll $\mathrm{b}$, which is exclusively found in the pigment antenna system of PSII. Thus, the reduced amount of chlorophyll a/b ratio could be due to the enlargement of the antenna system of PSII over time, which positively correlates with the light-harvesting chlorophyll-protein complex (LCHII) $[42,43]$.

Different shading levels also significantly influence the leaf temperature, transpiration rate, and stomatal conductance of P. minus. Low leaf temperature under control, T1 as compared to other shading levels is due to the effect of evaporative leaf cooling that will cause a reduction in leaf temperature, as the temperature of the surrounding will indirectly increase under high light intensity [44]. Leaf temperature has also been found to be closely related to many other physiological aspects of plants, especially on the photosynthesis rate and accumulation of pigments [45]. Hence, a high significant positive correlation can be observed between leaf temperature and in- situ chlorophyll $\left(\mathrm{r}^{2}=0.850, p \leq 0.01\right)$ (Table 2). In-situ chlorophyll influences the leaf temperature by determining the amount of sunlight absorbed that will further excite the photons, creating energy for the assimilation process and producing heat within the plant [46]. The values of E and Gs were both significantly influenced by the different shading levels and strongly correlated with each 
other $\left(\mathrm{r}^{2}=0.972 ; p \leq 0.01\right)$, as the degree of the opening and closing of the stomata will control the rate of transpiration. This strong correlation also suggests that the transpiration rate in this study was strongly influenced by stomatal regulation. The closing and opening of stomata at the same time depends on the turgor pressure of the guard cells, which could easily be influenced by light changes [47]. Plants under control, T1 exhibits a low E due to the loss of turgidity in leaves that is caused by the drier air that resulted by the high light intensity, thus reducing the transpiration rate as the stomata close [48]. Low light intensity may lead to a higher relative humidity in the surrounding, which caused a decrease in abscisic acid that regulates the stomatal movement [49], contributing to the malfunctioning of the stomata [50]. This result is parallel with the value of low Gs obtained under T3, and this value was not significantly different with the value of Gs under T1. There were strong correlations between transpiration rate with $\mathrm{Chl}$ a $\left(\mathrm{r}^{2}=0.653 ; p \leq 0.01\right)$, $\mathrm{Chl} \mathrm{b}\left(\mathrm{r}^{2}=0.553 ; p \leq 0.01\right)$, and Chl $\mathrm{a}+\mathrm{b}\left(\mathrm{r}^{2}=0.61 ; p \leq 0.05\right)$ (Table 2). These correlations seemed to be complex, as the transpiration rate and stomatal conductance are more closely correlated with the process of photosynthesis through the intake of $\mathrm{CO}_{2}$ and diffusion of water vapour [51]. We assumed that these significant correlations indicate that the key factor of the increased photosynthesis rate under intermediate light intensity was due to the increased in leaf pigments content, thus affecting the transpiration rate and stomatal conductance that were observed in this study.

Different shading levels as well as duration of treatment exposure were found to be significantly influenced the production of TAC, TPC, and TFC in P. minus leaves. P. minus leaves that were grown under T3 were found with the highest amount of anthocyanin (TAC) after eight weeks of exposure, but the highest after 16 weeks of exposure show under T2 as compared to other treatments. This result is in contrast to other few studies, which reported that high light intensity induced the production of anthocyanin [52,53]. This is because low light condition is often paired with low photosynthesis, which restricts the production of carbohydrates that play a significant role in anthocyanin biosynthesis [54]. However, such a condition was not observed in this study. These show that P.minus under intermediate light intensity is able to give a high photosynthesis rate, thus increasing the anthocyanin synthesis. A strong correlation was observed between TAC with carotenoid content in this study, where $\mathrm{r}^{2}=0.549, p \leq 0.05$ (Table 2). The biosynthetic pathways of both carotenoid and anthocyanin were well established; however, these two pathways were not directly inter-related. Nevertheless, these pathways may be overlapping at the level of induction in response to various stimuli [55], which, in this study, is the light intensity.

The productions of TPC and TFC in the leaves of $P$. minus are the highest under T2 for samples harvested after 8 weeks of treatment exposure. In contrast, after 16 weeks of treatment exposure, $70 \%$ shading under T3 was observed to yield the highest amount of TPC and TFC in P. minus leaves, being much higher than the TPC and TFC recorded after eight weeks of treatment. The higher production of TPC and TFC under low light condition is aligned with the results obtained in Orthosiphon stimaneus [56], which showed that the increase may be due to the increase in the availability of phenylalanine enzyme that ushers the production of carbon-based secondary metabolites, including phenolic and flavonoid compounds. The increase of the photosynthesis rate under $\mathrm{T} 2$ due to the increase in-situ chlorophyll content shows the increase of the production of secondary metabolites that are derived from the photosynthetically-produced carbohydrate under the shikimic acid pathway [18,57], as high in-situ chlorophyll indicates a greater amount of sunlight absorption that will produce a higher photosynthesis process, annotated by high correlation between TPC and TFC with in-situ chlorophyll, SPAD $\left(\mathrm{r}^{2}=0.744, p \leq 0.01\right.$ and $\mathrm{r}^{2}=0.644 ; p<0.05$ (Table 2), respectively. The production and accumulation of carbonbased secondary metabolites show significantly correlated with the in-situ chlorophyll content, indicating that the in-situ chlorophyll that is capable of predicting the production of phenolic and flavonoid compounds. High significant correlations are also observed between TPC and TFC with Tleaves, with $\mathrm{r}^{2}$ values of $0.798, p \leq 0.01$ and $0.693, p \leq 0.05$. We assumed the correlations with Tleaves were highly affected by the values of SPAD, 
since they were also strongly correlated (Table 2). Meanwhile, a strong correlation between TPC and TFC with a $\mathrm{r}^{2}$ value of $0.889, p \leq 0.001$ shows that, as the TPC increases, the value of TFC will also increase and this will improve the medicinal value of $P$. minus. The presence of flavonoid is crucial in indicating the biological activity for anti-inflammatory, antiallergic, antiviral, anticarcinogenic activities, and the most important for antioxidant activity due to its ability to reduce free radical formation and scavenge free radical [58]. Several studies reported that phytocompounds found in P. minus, such as phenolic and flavonoid, contribute the most to antioxidative and anti-inflammatory activities [59]. In comparison with other medical plants, P. minus had been reported to obtain high phenolic content compared to Curcuma longa and Zingiber officinale [6]. Therefore, the current study suggested Polygonum minus to be able to enhance its medicinal properties through shading. Antioxidant agents are believed to be able to prevent carcinogenesis and atherogenesis responsible for cancer and cardiovascular diseases, by passively interfering with oxidative damage to DNA and lipoproteins [60]. Existing data on the usage of antioxidant compounds and chemotherapy showed that antioxidant supplementation led to an improvement in treatment outcomes, increased survival times, higher anti-tumour response, and reduced toxicity [61]. The longer exposure of 16 weeks under a shading level of 50\% (T2) has been seen to significantly improve the antioxidant properties of $P$. minus as compared to eight weeks. Shading have been reported to improve antioxidant properties in Coffea arabica [62] and Zingiber officinale [17], but in contrast to what have been reported on Labisia pumila [63] and on the greenhouse-grown lettuce [64]. Based on this research, antioxidant activity was highly affected by the level of $\mathrm{Chl}$ a, Chl b, Car, and TAC instead of the values of TPC and TFC due to high correlation values that are shown in Table 2. This shows that the antioxidant properties in $P$. minus are not mainly contributed by the production of TPC and TFC, which aligned with the result that was reported by Mahmud et al., 2019 [65]. Carotenoids and anthocyanin have both long been known as efficient antioxidants, in addition of anthocyanin compound being part of the flavonoid group [66-68]. A negative significant correlation between FRAP and DPPH (Table 2) assay shows, that as the value of FRAP reducing power increases, a lesser concentration of $P$. minus extract is needed to inhibit 50\% of DPPH radical species.

\section{Materials and Methods}

\subsection{Treatments Description and Maintanance}

The study was carried out in Rimba Ilmu Botanical Garden greenhouse, University of Malaya. P. minus plants were propagated for two weeks before being transplanted to media; polyethylene bags that were filled with soilless mixture of burnt rice husk and coco peat in the ratio of 3:1, respectively. Three treatments of shading levels: $0 \%$ shading (Control, T1), 50\% shading (T2), and 70\% shading (T3) were arranged in a Randomized Complete Block Design with 3 shading levels $\times 4$ blocks $\times 8$ replicates. The percentage of shade levels are based on the density of the nylon mesh of the commercial shade cloth. The manufacturers provided this information. The shade levels (T2 and T3) were prepared in rows where the shade levels were represented by black nylon netting canvas with different mesh percentage. The canvas was installed from wall to wall of the greenhouse, forming horizontal shading above the plants in each treatment row. Inner walls were also installed around the shaded compartments, to make sure that all plants were covered. The light intensities were continuously monitored by using a LI-COR LI-250A light meter to ensure the significant range of differences between treatments. The average light intensity $\left(\mu \mathrm{mol} \mathrm{m} \mathrm{m}^{-2} \mathrm{~s}^{-1}\right.$ ) measured under different shading levels during experiment showed that (T1) $0 \%$ shading, the control recorded $80.024 \mathrm{a} \pm 6.476$, (T2) 50\% shading recorded $29.927 \mathrm{~b} \pm 4.859$, and (T3) $70 \%$ shading recorded $11.698 \mathrm{c} \pm 1.018$. All of the plants were watered sufficiently every morning and fertilised using NPK green fertilizer (NPK ratio: 10:20:10) once per week. 


\subsection{Plant Growth}

Plant height $(\mathrm{PH})$ and leaves number (LN) were measured every two days until the 25th day after transplant. The plant height measurements were taken on the main stem from the reference point on the soil surface towards the tip of the stem by using a measuring tape with an accuracy of $\pm 1 \mathrm{~mm}$. The number of leaves was recorded in total per plant. All of the data were recorded in eight replicates for each block under all treatments.

\subsection{Biomass Dry Weight and Root-Shoot Ratio}

Plants were harvested after a time interval of eight weeks and 16 weeks of planting to measure the leaves dry weight (LDW), shoot dry weight (SDW), and root dry weight $(\mathrm{RDW})$. One harvest time measured for 4 replicates $\times 4$ blocks of all treatments. The harvested plants were divided into different plant parts (leaves, shoots, and roots). All parts were subjected to freeze-drying process using Labconco freeze dryer (Labconco Corporation, MO 64132 USA) at $-50^{\circ} \mathrm{C}$. The dry weights of the plant were recorded as the biomass dry weight. The root-shoot ratio was calculated by dividing root dry weight with the above ground dry weight [69].

\subsection{Leaf Gas Exchange}

The measurements of photosynthesis rate (A), leaf temperature (Tleaves), transpiration rate $(\mathrm{E})$, and stomatal conductance (Gs) were obtained by a closed infra-red gas analyser LICOR 6400 Portable Photosynthesis System (IRGA, Licor Inc., Lincoln, NE, USA). The measurements used an optimal condition set of $400 \mu \mathrm{mol} \mathrm{mol}^{-1} \mathrm{CO}_{2}$ flux, $30^{\circ} \mathrm{C}$ standard cuvette temperature, and PAR of $1200 \mu \mathrm{mol} \mathrm{m}^{-2} \mathrm{~s}^{-1}$ [70]. Leaf gas exchange measurements were carried out between 10:00 a.m. to 11:00 a.m., on the third fully expanded leaves from the plant apex. The data were recorded in triplicates from each treatment within each block.

\subsection{In-Situ Chlorophyll Content}

In-situ chlorophyll content (SPAD) was recorded using a SPAD-502 meter (Konica Minolta Optic Inc., Tokyo, Japan) once every three days on a mature expanded leaf of each plant. The equipment was calibrated prior to the measurements. The data were recorded in triplicates from each treatment within each block.

\subsection{Leaf Chlorophyll and Carotenoid Analysis}

The chlorophyll a (Chl a), chlorophyll b ( $\mathrm{Chl}$ b), and carotenoid (Car) were analysed from young, expanded leaves. Approximately $0.1 \mathrm{~g}$ leaf sample was crushed in liquid nitrogen by using mortar and pestle. The sample was ground in $10 \mathrm{~mL}$ absolute methanol using chilled mortar and pestle before being incubated under $-20^{\circ} \mathrm{C}$ in the dark for $24 \mathrm{~h}$. The relative chlorophyll and carotenoid levels were measured in triplicates with a spectrophotometer (Thermo Scientific Multiskan GO) at 665.2, 652.4, and $470 \mathrm{~nm}$ wavelengths after 10 -fold dilution. The pigment concentrations of chlorophyll a, chlorophyll $b$, and carotenoid were calculated following the methods by Lichtenthaler and Claus, 2001 [42], and then expressed as $\mathrm{mg}$ chlorophyll $\mathrm{g}^{-1}$ tissue fresh weight $\left(\mathrm{mg} \mathrm{g}^{-1} \mathrm{FW}\right)$. Next, the total chlorophyll $(\mathrm{Chl} \mathrm{a}+\mathrm{b})$ and chlorophyll $\mathrm{a}$ and $\mathrm{b}$ ratio $(\mathrm{Chl} \mathrm{a} / \mathrm{b})$ were calculated following Li et al., 2018 [71].

$$
\begin{aligned}
& \text { Chl a ( } \mu \mathrm{g} / \mathrm{mL}): 16.72(\mathrm{~A} 665.2)-9.16(\mathrm{~A} 652.4) \\
& \text { Chl b ( } \mu \mathrm{g} / \mathrm{mL}): 34.9 \text { (A652.4) - } 15.28 \text { (A665.2) } \\
& \text { Car }(\mu \mathrm{g} / \mathrm{mL}):(1000(\mathrm{~A} 470)-(1.63(\mathrm{Chl} \mathrm{a})-104.96(\mathrm{Chlb})) / 221
\end{aligned}
$$

\subsection{Total Anthocyanin Content}

The extraction process that was used for the total anthocyanin content (TAC) assay was conducted, as previously described by Giusti and Wrolstad, 2001 [72] using pH differential method with some modifications. $0.2 \mathrm{~g}$ of freeze dried leaves was ground in $10 \mathrm{~mL}$ of 
absolute methanol. The methanolic extract was separately diluted with two types of buffer: potassium chloride $(0.025 \mathrm{M})$ at $\mathrm{pH} 1.0$ and sodium acetate $(0.4 \mathrm{M})$ at $\mathrm{pH} 4.5$ using the ratio 1:4 (one part test portion and four parts buffer). The absorbance of the samples was measured at 510 and $700 \mathrm{~nm}$. The TAC was calculated while using the following formula:

$$
\text { Total anthocyanin content }(\mathrm{mg} / \mathrm{L})=\mathrm{Ab} \times \mathrm{MW} \times \mathrm{df} \times 1000 \times \varepsilon \times 1
$$

where

$$
\begin{aligned}
& \mathrm{Ab}=(\mathrm{A} 510-\mathrm{A} 700) \mathrm{pH} 1.0-(\mathrm{A} 510-\mathrm{A} 700) \mathrm{pH} 4.5 \\
& \mathrm{MW}=\text { Molecular weight of cyanidin-3-glucosode }(449.2 \mathrm{~g} / \mathrm{mol}) \\
& \mathrm{df}=\text { the dilution factor } \\
& \varepsilon=\text { Extraction coefficient }(296,000 \mathrm{~mol} / \mathrm{g})
\end{aligned}
$$

\subsection{Total Phenolic and Flavonoid Content}

The extraction and quantification for total phenolic and flavonoid contents followed the methods that were described by Yusof et al., 2018 [73]. The leaf samples were harvested over two time intervals (eight weeks and 16 weeks). The methanolic extract of $P$. minus was prepared after the leaf samples were freeze-dried. $0.5 \mathrm{~g}$ of freeze dried leaves were soaked and ground in $30 \mathrm{~mL}$ of absolute methanol using chilled mortar and pestle. The sample mixtures were then incubated at $-20^{\circ} \mathrm{C}$ for $24 \mathrm{~h}$ before being filtered using filter paper. The filtrates were pooled and then evaporated under $45^{\circ} \mathrm{C}$ using rotary evaporator before adjusted to a concentration of $20 \mathrm{mg} \mathrm{mL}^{-1}$.

Folin-Ciocalteu reagent (10\%) was used to determine the total phenolics content (TPC) of the leaf samples. $0.1 \mathrm{~mL}$ of the sample extract was mixed with Folin-Ciocalteu reagent $(0.75 \mathrm{~mL}) .2 \%$ aqueous sodium carbonate $(0.75 \mathrm{~mL})$ was added into a test tube and then incubated in the dark for $45 \mathrm{~min}$. The blanks were prepared by using absolute methanol and the absorbance was recorded at $765 \mathrm{~nm}$. Standard calibration curve was prepared with a series of gallic acid standards $(0.01,0.02,0.03,0.04,0.05$, and $0.06 \mathrm{mg} / \mathrm{mL})$. The results were represented as $\mathrm{mg} \mathrm{g}^{-1}$ dry weight of leaves $\left(\mathrm{mg} \mathrm{g}^{-1} \mathrm{DW}\right)$. For total flavonoid content (TFC), $0.5 \mathrm{~mL}$ of the sample was mixed with $1.5 \mathrm{~mL}$ of absolute methanol in a test tube that was covered with aluminium foil, and it was left for $5 \mathrm{~min}$. Next, $10 \% 0.10 \mathrm{~mL}$ of $\mathrm{AlCl}_{3}$ $\left(\mathrm{AlCl}_{3} \bullet 6 \mathrm{H}_{2} \mathrm{O}\right)$ was added followed by the addition of $0.1 \mathrm{~mL} \mathrm{NaOH} 1 \mathrm{M}$ and $2.8 \mathrm{~mL}$ of distilled water. The absorbance was measured at $415 \mathrm{~nm}$ after $40 \mathrm{~min}$. of incubation with quercetin as a standard and the results were expressed as $\mathrm{mg} \mathrm{g}^{-1}$ dry weight of leaves (mg g $\left.{ }^{-1} \mathrm{DW}\right)$.

\subsection{Ferric Reducing Antioxidant Power (FRAP)}

The FRAP assay was performed based on the method that was described by Benzie \& Strain, 1999 [74] with slight modifications. Approximately $300 \mu \mathrm{L}$ of methanolic plant extract was mixed with $10 \mu \mathrm{L}$ FRAP reagent and it was incubated in microplate wells at room temperature in the dark for $30 \mathrm{~min}$. The absorbance was recorded at $593 \mathrm{~nm}$. A series of stock solution at 1.0, 2.0, 3.0, 4.0, 5.0, and $6.0 \mathrm{mg} / \mathrm{mL}$ of ferrous sulphate $\left(\mathrm{FeSO}_{4}\right)$ were prepared to generate a standard curve $\left(\mathrm{r}^{2}=0.9902\right)$. The results obtained were expressed as $\mathrm{mg}$ of ferrous sulphate equivalent per gram of dried extract.

\subsection{DPPH Radical Scavenging Assay}

The 2,2-Diphenyl-1-picrylhydrazyl (DPPH) free radical scavenging activity of each sample was determined according to the method that was described by Yusof et al., 2018 [73]. $50 \mu \mathrm{L}$ of extract at six different concentrations $(0.5,1.0,2.0,3.0,4.0$, and $5.0 \mathrm{mg} / \mathrm{mL}$ ) was added to $150 \mu \mathrm{L}$ of DPPH solution $(60 \mathrm{mM})$ in each well of a 96-well plate. The change in absorbance at $515 \mathrm{~nm}$ was measured after $30 \mathrm{~min}$. incubation in room temperature. The obtained data will then be used to determine the concentration of the sample that is required to scavenge $50 \%$ of the DPPH free radicals $\left(\mathrm{IC}_{50}\right)$. The percentage of inhibition was plotted against the concentration and the $\mathrm{IC}_{50}$ was obtained from the fitted linear curve. A lower $\mathrm{IC}_{50}$ denotes a more potent antioxidant. 


\subsection{Statistical Analysis}

All of the data were analysed using the SPSS Processor (Statistical Package for the Social Sciences, Version 25) for descriptive statistics and one-way analysis of variance (ANOVA) with Tukey's post hoc test at a $5 \%$ level of probability in significant difference. The standard error of differences between the means was calculated with the assumption that the data were normally distributed and equally replicated. The association and relationships between parameters are shown using Pearson's correlation analysis.

\section{Conclusions}

From the study, it was found that control ( $0 \%$ shading level) produced highest plant biomass; however, a 50\% shading level show the highest leaf gas exchange properties, leaf pigment contents, and secondary metabolites (TAC, TPC), including antioxidant properties (FRAP). Under $50 \%$ shading level, P. minus showed adaptation well up to 16 weeks' exposure. It was found P. minus might tolerate low light intensity by an increase in its chlorophyll content, photosynthesis rate, transpiration rate, TAC, TPC, and FRAP, while reducing DPPH, which indicates high antioxidant properties under these conditions.

Author Contributions: F.F.M.Y., N.A.M.Z. and J.S.Y. conceived and designed the experiments. F.F.M.Y. conducted the experiments, collected the data and performed the statistical analysis. N.A.M.Z. and J.S.Y. advised on the preparation of materials. M.H.I., Z.B. and N.O. provided the facilities for measurement. F.F.M.Y. wrote the manuscript. N.A.M.Z., J.S.Y. and W.A.A.Q.I.W.-M. read an edited the manuscript. All authors approved the final manuscript. All authors have read and agreed to the published version of the manuscript.

Funding: This research was funded by Long Term Research Grant Scheme (LRGS) (LR003-2020), and Research University grant (GPF009B-2018).

Acknowledgments: We sincerely thank University of Malaya for the facilities provided.

Conflicts of Interest: There is no conflict of interest for this journal article.

\section{References}

1. Rusdi, N.A.; Goh, H.-H.; Baharum, S.N. GC-MS/Olfactometric characterisation and aroma extraction dilution analysis of aroma active compounds in Polygonum minus essential oil. Plant Omics 2016, 9, 289-291. [CrossRef]

2. Christapher, P.V.; Parasuraman, S.; Christina, J.M.A.; Vikneswaran, M.; Asmawi, M.Z. Review onPolygonum minus. Huds, a commonly used food additive in Southeast Asia. Pharmacogn. Res. 2015, 7, 1-6. [CrossRef]

3. Baharum, S.N.; Bunawan, H.; Ghani, M.A.; Mustapha, W.A.W.; Noor, N.M. Analysis of the Chemical Composition of the Essential Oil of Polygonum minus Huds. Using Two-Dimensional Gas Chromatography-Time-of-Flight Mass Spectrometry (GC-TOF MS). Molecules 2010, 15, 7006-7015. [CrossRef] [PubMed]

4. Vikram, P.; Chiruvella, K.K.; Ripain, I.H.A.; Arifullah, M.; Hua, G.S. A recent review on phytochemical constituents and medicinal properties of kesum (Polygonum minus Huds.). Asian Pac. J. Trop. Biomed. 2014, 4, 430-435. [CrossRef]

5. Qader, S.W.; Abdulla, M.A.; Chua, L.S.; Hamdan, S. Potential Bioactive Property of Polygonum minus Huds (kesum) Review. Sci. Res. Essays 2012, 7, 90-93. [CrossRef]

6. Maizura, M.; Aminah, A.; Wan Aida, W.M. Total Phenolic Content and Antioxidant Activity of Kesum (Polygonum minus), ginger (Zingiber officinale) and Turmeric (Curcuma longa) Extract. Int. Food Res. J. 2011, 18, 526-531.

7. You, Y.; Shahar, S.; Haron, H.; Yahya, H.M. More Ulam for Your Brain: A Review on the Potential Role of Ulam in Protecting Against Cognitive Decline. Sains Malays. 2018, 47, 2713-2729. [CrossRef]

8. Ghazali, M.A.M.; Al-Naqeb, G.; Selvarajan, K.K.; Hasan, M.H.; Adam, A. Apoptosis Induction byPolygonum minusIs Related to Antioxidant Capacity, Alterations in Expression of Apoptotic-Related Genes, and S-Phase Cell Cycle Arrest in HepG2 Cell Line. BioMed Res. Int. 2014, 2014, 539607. [CrossRef]

9. Ahmad, R.; Sahidin, I.; Taher, M.; Low, C.; Noor, N.M.; Sillapachaiyaporn, C.; Chuchawankul, S.; Sarachana, T.; Tencomnao, T.; Iskandar, F.; et al. Polygonumins A, a newly isolated compound from the stem of Polygonum minus Huds with potential medicinal activities. Sci. Rep. 2018, 8, 1-15. [CrossRef] [PubMed]

10. Kurata, H.; Matsumura, S.; Furusaki, S. Light irradiation causes physiological and metabolic changes for purine alkaloid production by a Coffea arabica cell suspension culture. Plant Sci. 1997, 123, 197-203. [CrossRef]

11. Briskin, D.P.; Gawienowski, M.C. Differential effects of light and nitrogen on production of hypericins and leaf glands in Hypericum perforatum. Plant Physiol. Biochem. 2001, 39, 1075-1081. [CrossRef]

12. Affendy, H.; Aminuddin, M.; Arifin, A.; Mandy, M.; Julius, K.; Tamer, A. Effects of Light Intensity on Orthosiphon stamineus Benth. Seedlings Treated with Different Organic Fertilizers. Int. J. Agric. Res. 2010, 5, 201-207. [CrossRef] 
13. Pan, J.; Guo, B. Effects of Light Intensity on the Growth, Photosynthetic Characteristics, and Flavonoid Content of Epimedium pseudowushanense BL Guo. Molecules 2016, 21, 1475. [CrossRef] [PubMed]

14. Fan, X.-X.; Xu, Z.-G.; Liu, X.-Y.; Tang, C.-M.; Wang, L.-W.; Han, X.-L. Effects of light intensity on the growth and leaf development of young tomato plants grown under a combination of red and blue light. Sci. Hortic. 2013, 153, 50-55. [CrossRef]

15. Liu, Q.-H.; Wu, X.; Chen, B.-C.; Ma, J.-Q.; Gao, J. Effects of Low Light on Agronomic and Physiological Characteristics of Rice Including Grain Yield and Quality. Rice Sci. 2014, 21, 243-251. [CrossRef]

16. Zhu, H.; Li, X.; Zhai, W.; Liu, Y.; Gao, Q.; Liu, J.; Ren, L.; Chen, H.; Zhu, Y. Effects of low light on photosynthetic properties, antioxidant enzyme activity, and anthocyanin accumulation in purple pak-choi (Brassica campestris ssp. Chinensis Makino). PLoS ONE 2017, 12, e0179305. [CrossRef] [PubMed]

17. Ghasemzadeh, A.; Jaafar, H.Z.E.; Rahmat, A.; Wahab, P.E.M.; Halim, M.R.A. Effect of Different Light Intensities on Total Phenolics and Flavonoids Synthesis and Anti-oxidant Activities in Young Ginger Varieties (Zingiber officinale Roscoe). Int. J. Mol. Sci. 2010, 11, 3885-3897. [CrossRef]

18. Ibrahim, M.H.; Jaafar, H.Z.E.; Karimi, E.; Ghasemzadeh, A. Allocation of Secondary Metabolites, Photosynthetic Capacity, and Antioxidant Activity of Kacip Fatimah (Labisia pumilaBenth) in Response toCO2and Light Intensity. Sci. World J. 2014, 2014, 1-13. [CrossRef]

19. Morelli, G.; Ruberti, I. Shade Avoidance Responses. Driving Auxin along Lateral Routes. Plant Physiol. 2000, 122, 621-626. [CrossRef]

20. Ding, Z.; Galvan-Ampudia, C.S.; Demarsy, E.; Łangowski, Ł.; Kleine-Vehn, J.; Fan, Y.; Morita, M.T.; Tasaka, M.; Fankhauser, C.; Offringa, R.; et al. Light-mediated polarization of the PIN3 auxin transporter for the phototropic response in Arabidopsis. Nat. Cell Biol. 2011, 13, 447-452. [CrossRef]

21. Semchenko, M.; Lepik, M.; Götzenberger, L.; Zobel, K. Positive effect of shade on plant growth: Amelioration of stress or active regulation of growth rate? J. Ecol. 2011, 100, 459-466. [CrossRef]

22. Falster, D.S.; Westoby, M. Plant height and evolutionary games. Trends Ecol. Evol. 2003, 18, 337-343. [CrossRef]

23. Paez, A.; Gebre, G.M.; Gonzalez, E.M.; Tschaplinski, T.J. Growth, soluble carbohydrates, and aloin concentration of Aloe vera plants exposed to three irradiance levels. Environ. Exp. Bot. 2000, 44, 133-139. [CrossRef]

24. Silva, F.G.; Pinto, J.E.B.P.; Cardoso, M.D.G.; Nascimento, E.A.; Nelson, D.L.; Sales, J.D.F.; Mol, D.J.D.S. Influence of radiation level on plant growth, yield and quality of essential oil in carqueja. Ciência Agrotecnologia 2006, 30, 52-57. [CrossRef]

25. Vanneste, S.; Friml, J. Auxin: A Trigger for Change in Plant Development. Cell 2009, 136, 1005-1016. [CrossRef]

26. Yang, X.-Y.; Ye, X.-F.; Liu, G.-S.; Wei, H.-Q.; Wang, Y. Effects of light intensity on morphological and physiological characteristics of tobacco seedlings. J. Appl. Ecol. 2007, 18, 2642-2645.

27. Butler, R.D. The Effect of Light Intensity on Stem and Leaf Growth in Broad Bean Seedlings. J. Exp. Bot. 1963, 14, 142-152. [CrossRef]

28. Makino, A.; Sato, T.; Nakano, H.; Mae, T. Leaf photosynthesis, plant growth and nitrogen allocation in rice under different irradiances. Planta 1997, 203, 390-398. [CrossRef]

29. Zervoudakis, G.; Salahas, G.; Kaspiris, G.; Konstantopoulou, E. Influence of light intensity on growth and physiological characteristics of common sage (Salvia officinalis L.). Braz. Arch. Biol. Technol. 2012, 55, 89-95. [CrossRef]

30. Xie, S.; Luo, X. Effect of leaf position and age on anatomical structure, photosynthesis, stomatal conductance and transpiration of Asian pear. Bot. Bull. Acad. Sin. 2003, 44. [CrossRef]

31. Jose, S.; Merritt, S.; Ramsey, C.L. Growth, nutrition, photosynthesis and transpiration responses of longleaf pine seedlings to light, water and nitrogen. For. Ecol. Manag. 2003, 180, 335-344. [CrossRef]

32. Harris, R.W. Root-shoot ratios. J. Arboric. 1992, 18, 39-42.

33. Poorter, H.; Nagel, O. The role of biomass allocation in the growth response of plants to different levels of light, CO2, nutrients and water: A quantitative review. Funct. Plant Biol. 2000, 27, 1191. [CrossRef]

34. Fernandes, V.F.; De Almeida, L.B.; Feijó, E.V.D.S.; Silva, D.D.C.; De Oliveira, R.A.; Mielke, M.S.; Costa, L.C.D.B. Light intensity on growth, leaf micromorphology and essential oil production of Ocimum gratissimum. Rev. Bras. Farm. 2013, 23, 419-424. [CrossRef]

35. Shipley, B.; Meziane, D. The balanced-growth hypothesis and the allometry of leaf and root biomass allocation. Funct. Ecol. 2002, 16, 326-331. [CrossRef]

36. Mielke, M.S.; Schaffer, B. Photosynthetic and growth responses of Eugenia uniflora L. seedlings to soil flooding and light intensity. Environ. Exp. Bot. 2010, 68, 113-121. [CrossRef]

37. Dai, Y.; Shen, Z.; Liu, Y.; Wang, L.; Hannaway, D.; Lu, H. Effects of shade treatments on the photosynthetic capacity, chlorophyll fluorescence, and chlorophyll content of Tetrastigma hemsleyanum Diels et Gilg. Environ. Exp. Bot. 2009, 65, 177-182. [CrossRef]

38. Dordas, C.A.; Sioulas, C. Safflower yield, chlorophyll content, photosynthesis, and water use efficiency response to nitrogen fertilization under rainfed conditions. Ind. Crops Prod. 2008, 27, 75-85. [CrossRef]

39. Walters, R.G. Towards an understanding of photosynthetic acclimation. J. Exp. Bot. 2004, 56, 435-447. [CrossRef]

40. Ormrod, D.P.; Lesser, V.M.; Olszyk, D.M.; Tingey, D.T. Elevated Temperature and Carbon Dioxide Affect Chlorophylls and Carotenoids in Douglas-Fir Seedlings. Int. J. Plant Sci. 1999, 160, 529-534. [CrossRef]

41. Bohne, F.; Linden, H. Regulation of carotenoid biosynthesis genes in response to light in Chlamydomonas reinhardtii. Biochim. Biophys. Acta (BBA) Gene Struct. Expr. 2002, 1579, 26-34. [CrossRef] 
42. Lichtenthaler, H.K.; Buschmann, C. Chlorophylls and Carotenoids: Measurement and Characterization by UV-VIS Spectroscopy. Curr. Protoc. Food Anal. Chem. 2001, 1, 4-15. [CrossRef]

43. Kitajima, K.; Hogan, K.P. Increases of chlorophyll a / b ratios during acclimation of tropical woody seedlings to nitrogen limitation and high light. Plant Cell Environ. 2003, 26, 857-865. [CrossRef] [PubMed]

44. Crawford, A.J.; McLachlan, D.H.; Hetherington, A.M.; Franklin, K.A. High temperature exposure increases plant cooling capacity. Curr. Biol. 2012, 22, 396-397. [CrossRef]

45. Haldimann, P. How do changes in temperature during growth affect leaf pigment composition and photosynthesis in Zea mays genotypes differing in sensitivity to low temperature? J. Exp. Bot. 1999, 50, 543-550. [CrossRef]

46. Canavar, Ö. Comparison and determination of the leaf temperature of sunflower and safflower under drought stress. Helia 2013, 36, 47-58. [CrossRef]

47. Kanemasu, E.T.; Tanner, C.B. Stomatal Diffusion Resistance of Snap Beans. I. Influence of Leaf-Water Potential. Plant Physiol. 1969, 44, 1547-1552. [CrossRef]

48. Bower, K.E. Relationship between Transpiration and Nitrogen Uptake by Pepper (Capsicum annuum) as Mediated by Vapor Pressure Deficit. Master's Thesis, The University of Georgia, Athens, GA, USA, 2005.

49. Bauer, H.; Ache, P.; Wohlfart, F.; Al-Rasheid, K.A.; Sonnewald, S.; Sonnewald, U.; Kneitz, S.; Hetherington, A.M.; Hedrich, R. How Do Stomata Sense Reductions in Atmospheric Relative Humidity? Mol. Plant 2013, 6, 1703-1706. [CrossRef]

50. Arve, L.E.; Terfa, M.T.; Gislerød, H.R.; Olsen, J.E.; Torre, S. High relative air humidity and continuous light reduce stomata functionality by affecting the ABA regulation in rose leaves. Plant Cell Environ. 2013, 36, 382-392. [CrossRef] [PubMed]

51. Maurel, C.; Verdoucq, L.; Rodrigues, O. Aquaporins and plant transpiration. Plant Cell Environ. 2016, 39, 2580-2587. [CrossRef]

52. Paiva, E.A.S.; Isaias, R.M.D.S.; Vale, F.H.A.; Queiroz, C.G.D.S. The influence of light intensity on anatomical structure and pigment contents of Tradescantia pallida (Rose) Hunt. cv. purpurea Boom (Commelinaceae) leaves. Braz. Arch. Biol. Technol. 2003, 46, 617-624. [CrossRef]

53. Nguyen, P.; Cin, V.D. The role of light on foliage colour development in coleus (Solenostemon scutellarioides (L.) Codd). Plant Physiol. Biochem. 2009, 47, 934-945. [CrossRef] [PubMed]

54. Kawabata, S.; Kusuhara, Y.; Li, Y.; Sakiyama, R. The Regulation of Anthocyanin Biosynthesis in Eustoma grandiflorum under Low Light Conditions. J. Jpn. Soc. Hortic. Sci. 1999, 68, 519-526. [CrossRef]

55. Dhar, M.K.; Sharma, R.; Koul, A.; Kaul, S. Development of fruit color in Solanaceae: A story of two biosynthetic pathways. Briefings Funct. Genom. 2015, 14, 199-212. [CrossRef]

56. Ibrahim, M.H.; Jaafar, H.Z.E. Primary, Secondary Metabolites, H2O2, Malondialdehyde and Photosynthetic Responses of Orthosiphon stimaneus Benth. to Different Irradiance Levels. Molecules 2012, 17, 1159-1176. [CrossRef]

57. Cevahir, G.; Yentur, S.; Yazgan, M.E.V.Z.U.L.E.; Unal, M.; Yilmazer, N.A.D.I.M. Peroxidase activity in relation to anthocyanin and chlorophyll content in juvenile and adult leaves of "mini-star" Gazania splendens. Pak. J. Bot. 2004, 36, 603-610.

58. Seyoum, A.; Asres, K.; El-Fiky, F.K. Structure-radical scavenging activity relationships of flavonoids. Phytochemistry 2006, 67, 2058-2070. [CrossRef]

59. Hamid, A.A.; Aminuddin, A.; Yunus, M.H.M.; Murthy, J.K.; Hui, C.K.; Ugusman, A. Antioxidative and anti-inflammatory activities of Polygonum minus: A review of literature. Rev. Cardiovasc. Med. 2020, 21, 275-287. [CrossRef] [PubMed]

60. Greenberg, E.R.; Sporn, M.B. Antioxidant Vitamins, Cancer, and Cardiovascular Disease. N. Engl. J. Med. 1996, 334, 1189-1190. [CrossRef]

61. Block, K.I.; Koch, A.C.; Mead, M.N.; Tothy, P.K.; Newman, R.A.; Gyllenhaal, C. Impact of antioxidant supplementation on chemotherapeutic toxicity: A systematic review of the evidence from randomized controlled trials. Int. J. Cancer 2008, 123, 1227-1239. [CrossRef] [PubMed]

62. Somporn, C.; Kamtuo, A.; Theerakulpisut, P.; Siriamornpun, S. Effect of shading on yield, sugar content, phenolic acids and antioxidant property of coffee beans (Coffea Arabica L. cv. Catimor) harvested from north-eastern Thailand. J. Sci. Food Agric. 2012, 92, 1956-1963. [CrossRef] [PubMed]

63. Karimi, E.; Jaafar, H.Z.; Ghasemzadeh, A.; Ibrahim, M.H. Light intensity effects on production and antioxidant activity of flavonoids and phenolic compounds in leaves, stems and roots of three varieties of Labisia pumila Benth. Aust. J. Crops Sci. 2013, 7, 1016 .

64. Stagnari, F.; Galieni, A.; Pisante, M. Shading and nitrogen management affect quality, safety and yield of greenhouse-grown leaf lettuce. Sci. Hortic. 2015, 192, 70-79. [CrossRef]

65. Mahmud, M.; Ramasamy, S.; Othman, R.; Abdullah, R.; Yaacob, J.S. Effect of Vermicompost Application on Bioactive Properties and Antioxidant Potential of MD2 Pineapple Fruits. Agronomy 2019, 9, 97. [CrossRef]

66. Stahl, W.; Sies, H. Antioxidant activity of carotenoids. Mol. Asp. Med. 2003, 24, 345-351. [CrossRef]

67. Williams, C.A. Anthocyanins and other flavonoids. Nat. Prod. Rep. 2004, 21, 539-573. [CrossRef]

68. Miguel, M.G. Anthocyanins: Antioxidant and/or anti-inflammatory activities. J. Appl. Pharm. Sci. 2011, 1, 7-15.

69. Sanquetta, C.R.; Corte, A.P.; Da Silva, F. Biomass expansion factor and root-to-shoot ratio for Pinus in Brazil. Carbon Balance Manag. 2011, 6, 6. [CrossRef]

70. Raai, M.N.; Zain, N.A.M.; Osman, N.; Rejab, N.A.; Sahruzaini, N.A.; Cheng, A. Effects of shading on the growth, development and yield of winged bean (Psophocarpus tetragonolobus). Ciência Rural 2020, 50. [CrossRef] 
71. Li, Y.; He, N.; Hou, J.; Xu, L.; Liu, C.; Zhang, J.; Wang, Q.; Zhang, X.; Wu, X. Factors Influencing Leaf Chlorophyll Content in Natural Forests at the Biome Scale. Front. Ecol. Evol. 2018, 6. [CrossRef]

72. Giusti, M.; Wrolstad, R.E. Characterization and Measurement of Anthocyanins by UV-Visible Spectroscopy. Curr. Protoc. Food Anal. Chem. 2001, 1, 1-2. [CrossRef]

73. Yusof, Z.; Ramasamy, S.; Mahmood, N.Z.; Yaacob, J.S. Vermicompost Supplementation Improves the Stability of Bioactive Anthocyanin and Phenolic Compounds in Clinacanthus nutans Lindau. Molecules 2018, 23, 1345. [CrossRef] [PubMed]

74. Benzie, I.F.; Strain, J. Ferric reducing/antioxidant power assay: Direct measure of total antioxidant activity of biological fluids and modified version for simultaneous measurement of total antioxidant power and ascorbic acid concentration. Methods Enzymol. 1999, 299, 15-27. [CrossRef] 